\title{
An Analysis of the Relationship Between City and Literature in Harold Bloom's Literary Places
}

\author{
Liu Yan $^{1}$ \\ ${ }^{1}$ School of Foreign Languages, Yancheng Normal University, Yancheng, China \\ Correspondence: Liu Yan, School of Foreign Languages, Yancheng Normal University, Yancheng, China. \\ E-mail: hobbyc@163.com
}

Received: August 30, 2021

Accepted: October 9, $2021 \quad$ Online Published: November 5, 2021

doi:10.5539/ijel.v11n6p140

URL: https://doi.org/10.5539/ijel.v11n6p140

\begin{abstract}
In terms of the relationship between city and literature, Harold Bloom in his works Literary Places points out city is the poetical dwelling and source of literature, while writers construct various images of city in the literature. By analyzing the relationship between city and literature, on one side, city is the matrix of literature. City provides writers with writing materials and opportunities to demonstrate the panorama of a city. On the other side, writer's works cultivate a kind of culture in a city and make the city come the unique literary capital.
\end{abstract}

Keywords: Harold Bloom, Literary Places, city, literature

\section{Introduction}

The relationship between city and literature has puzzled many writers and critics for decades. The city has always been regarded as the cradle of literature. All literary genres come from the city, and idyllic poem is one of them. The Bible is completed in the palace in Jerusalem. Dante and Petrarch's poems are closely connected with Rome. Montaigne takes Paris as the source of creation. Dickens's works focus on the panorama of London, and the works of Ginsburg and James brothers are linked with the image of New York. Writers and city are inextricably linked. The Image of city has become an essential element of literature. In the digital age, the charm of the city seems to have disappeared, and writers have lost inspiration and imagination to describe great changes in the city. Looking back on the past, at this moment, Literary Places published by American writer Harold Bloom in 2017 may make the public refocus on the city, awaking people's memory about these literary cities and restoring the charm of those brilliant literary temples.

In 2015, Peking University Press published The Republic of the literary world written by French critic Pascal Casanova, which has attracted extensive attention from domestic academic circles. In this book, the author puts forward a new point of view which holds that the literary world has its own boundary and geographical division; The territory of the literary world is completed according to its "aesthetic distance". The demand for the same standard in competing for the literary space leads to the "literary Greenwich Meridian". As a common measure and reference, literary meridian divides literary space. The author regards Paris as the center of the existing literary space, and national writers take this as the standard to measure their position in the space. This literary space is occupied by literary capitals such as Paris, London, New York and Dublin. The six volumes of Literary Places published by Harold Bloom in 2017 precisely involve six famous literary cities such as London, Paris, New York, Dublin, Rome and St. Petersburg as objects to clearly show the territory of world literature. In these books, the author tells the history of those cities in detail from the perspective of literature, discussing the subtle relationship between city and writers, telling writers' anecdotes. It is not only a literary monograph, but also a prose travel notes, so that readers can understand the literary stories behind the city and enjoy the beautiful urban scenery, which can be described as a spiritual literary pilgrimage.

\section{Literature Review}

Literary Places has won many writers' and scholars' attention. John Tomedi points out that this book introduces in detail the history of Dublin and the bright literary stars in this literary holy land. Dublin is full of a strong artistic and humanistic atmosphere everywhere. The whole work takes Dublin history as the main clue to combine the process of national development with those famous writers, such as W.B. Yeats. Jesse Zuba believes that Literary Places integrates history, geography, society, culture, art and literature. In a concise and 
comprehensive way, this book adopts interview, brief introduction, comment and other methods to outline the gorgeous literary landscape bred in the magical land of New York in the past three and a half centuries. Bradley Woodworth and Constance Richards claim that this book is full of pictures and texts which have traced the history of city and Literature, exploring the relationship between environment and writers to show the charming cultural landscape and brilliant literary achievements. Brett Foster and Hal Markowitz advocate that this book is based on the development of Roman literature. It has taken the rise and fall of Rome as the timeline to show readers a complete map of Roman literature. The author skillfully integrates history, religion, architecture and culture into literature. Mike Gerrard points out that this book integrates history, geography and Humanities, leading readers to feel the long literary history of city.

Yuntao once pointed out that since the 1960s, the space research has gradually become a trend, which also involves the literary theory. The study of urban culture is derived from the intersection of literature and geography. The geographical space of the city is paid more attention, while the literary space is paid less attention. Wang Chih-Hung points out that literary works and academic research are the cause of discourse construction. The intersection of multiple discourse and multiple reality in the city testify the close relationship between history and literature. Fu Xinghuan holds that the image of Petersburg in the Russian literature, as a complete symbol system, has always been a consistent discourse unit. These discourse units have always maintained relative stability in the two centuries' development, forming a huge hypertext system which shows the uniqueness of Petersburg's culture. Wang Xiaoyan claims that in Joseph Conrad's novel The Secret Agent, London is a symbol of the divine absence.

However, in terms of exact relationship between city and literature, there are also dissenting voices who claim that with the urbanization, the image of city has changed. City has lost its close connection with literature. Some critics even point out that city is now the center of commerce and no longer suitable for literary creation. Through the analysis of the relationship between city and literary in Harold Bloom's Literary Places, this paper aims to re-examine the connection between city and literature in the transition period between urban and rural areas in the United States and Europe, illustrating the distortion of the image of city in modern literature.

\section{An Analysis of the Relationship Between City and Literature in Harold Bloom's Literary Places}

\subsection{The Literary Map in Cities}

Most readers are familiar with the history of these famous literary cities. However, Bloom found another way to look at the process of history from the perspective of urban development and literature.

From the Norman Conquest to today, London has developed from a small town into a "rainbow of gravity", which gave birth to a large number of world-famous writers such as William Shakespeare. The development of medieval commerce gave birth to London. In the Tudor era, the improvement of citizens' educational level stimulated the development of domestic publishing industry. In the 16th century, trade and population doubled and London became a prosperous capital. There were many theaters, and playwrights such as Shakespeare. After the turbulent civil war, the class contradiction in London in the 18th century led to many social problems. Since the 19th century, London has witnessed the prosperity of the "The empire on which the sun never sets" and the two World Wars. From the Renaissance, romanticism, realism to aestheticism, literature changes with London. The development of the city reflects the Literary paradigm, and literature truly records changes of the city.

Casanova once regarded Paris as the center of world literature, and Bloom praises Paris for its inclusiveness and openness. "Whether in April or in autumn, Paris, the capital of France, has always been a place of inspiration for writers" (Gerrard, 2005, p. 1). About a Hundred years' prosperity of Paris created writers such as Rabelais, Moliere and La Fontaine. Voltaire and Diderot in the age of enlightenment bring French thought to the whole world. In the following two hundred years, French romantic, naturalistic and realistic writers appeared on the stage, witnessing the surging of the French Revolution and the rise and fall of the French Empire. Paris in the 20th century has also become a "holy place" for writers all over the world. Paris's rich artistic resources, picturesque scenery, representative landmarks and artists' pioneer ideas have provided rich creative resources for French local writers and immigrant writers.

Different from London and Paris, as an international city with a relatively short history, New York's development is amazing. As the world's capital of immigrants and a financial center, in many writers' eyes, the history of New York seems to be bound with wealth. The complex and diverse economic situation, the powerful industry, the rise of Wall Street, numerous museums and art centers all make this literary capital far from Europe with its unique charm. From the original small town, to an industrial city in the 19th century, and then to a modern metropolis, New York plays an increasingly important role in world literature. New York poets, painters and intellectuals record changes of New York's spirit clearly and accurately. 
The literary status of Dublin and St. Petersburg is closely related to their national destiny. Dublin has a long history and is widely praised in its heroic legends and legendary records, but the British colonial invasion has become a heavy burden on the Irish nation. Therefore, Dublin's literary scene is closely related to the British colonial rule, the spiritual awakening of the Irish nation and national independence. Dublin's history is the history of Irish writers' struggling for the literary discourse. St. Petersburg, located on the Neva River, is the cornerstone of new Russia, witnessing the ambition of Peter the great. It is always many writers' spiritual city. "Moscow is the central city of the Russian people, and St. Petersburg is now a foreign city. It shows the old baroque style and acts as the central capital of the Empire" (Woodworth \& Richards, 2005, p. 1). This passage is enough to affirm the historical position of St. Petersburg in the rise of the Russian nation. From Pushkin and Gogol to Dostoevsky and Pollock, St. Petersburg is not only the center of poetry, but also the capital of novels, thus ranking among the world literary capitals.

Compared with the above cities, the journey of urban literature in Rome is longer. Goethe once praised Rome: "if a man sees Rome, he sees everything" (Foster \& Markowitz, 2005, p. 1). Looking back on the long history and visiting many Roman relics, readers can see Dante and Petrarch's poems in my mind. They can feel citizens' life from Etruscans to the Republic and the Roman Empire, and recall the historical experience of Christianity here. As a literary pilgrimage capital, Rome still attracts writers from many countries. As one of the oldest countries in human history, the art and literature left by the Roman Empire are still talked about by the world. From building to ruling the world and then declining, the story of Rome is far richer than that of several other literary capitals.

As a critic and writer, Bloom integrates the fate of the six cities with literature and recalls its developing trace with a unique historical perspective, which enables readers to understand the history, the surprise and pleasure brought to us by well-known writers. Readers can purify their souls, as if they found an "oasis" in the busy urban life. On the title page of each book, the author uses maxims to guide readers to start their literary journey, and the list behind the text introduces the major events of each city and well-known literary relics to help readers deeply understand the six literary capitals. While being familiar with literary giants and their life tracks, it can also be used as a travel guide to help readers continue their interesting urban journey. Being close to the literary development of each city, this book shows the geographical features of the literary capital from the technique of flashback, which is true, credible and far-reaching.

\subsection{The Image of City in Literature}

"As far as their profession is concerned, literary masters always like to stay away from the world. But their hearts are eager to find their true friends in the literary and artistic circles at that time" (Gerrard, 2005, p. 6). The city provides them with the best creative place and communication space. There are countless connections between cities and writers. It is not only a place for writers to live, but also a place for their growth, creation, fame or loss. The development and oddity of cities have become valuable creative materials for writers, and cities are known by the world because of those classic works. Cities not only give birth to various styles, but also become the literary theme, the battlefield for writers to fight and the place for emotional expression. Writers' creation has also created the literary city. The relics left by the writer have been respected by the world and painted a strong color for the city.

Although Shakespeare's works mostly tell foreign stories, its real background has never been far from London. The experience in the global grand theater gives the writer precious life experience. Therefore, it can describe all kinds of life in urban society vividly, and let readers clearly understand the urban stories of London. Dickens' feelings for London are more complex. His unhappy childhood makes him pay attention to the dark side of London and reveals the difficult life of the lower class in the era of great industry. Stendhal, a literary master, described the turbulence of French society and the curse of desire during the restoration period in The Red and the Black; Balzac's "human comedy" can be regarded as a ukiyo painting of Paris; Hugo's Notre Dame de Paris has already become a representative building of the capital of literature. The sad and beautiful love story has deeply touched the hearts of thousands of young people.

Dublin, Joyce's hometown, has become a complex in the hearts of Irish writers. In these Irish writers' works, Dublin not only has a mysterious national color, but is also sung by legends. On the other hand, under the British colonial rule, Dublin seemed lifeless, just like a pool of stagnant water. Joyce describes such a scene more than once in his representative works Dubliners and Ulysses, to lament its misfortune and anger. The streets and houses in his works have now become Dublin's landmark buildings.

If Pushkin's "Bronze Knight" was inspired by the statue of St. Petersburg, Gogol's description of the city is more detailed and in-depth. The former one observes various social problems in Russia with keen eyes and exposed 
them; The latter one enlarges and ponders this problem with humorous and spicy way. Taking St. Petersburg as the prototype, Dostoevsky creates the novel Crime and Punishment, which not only describes landmark places such as hay market into the works, but also displays characters' inner world through the contrast of the environment, so that readers can feel people's real emotions in the turbulent period of Russia.

In terms of literature, Rome and New York are similar. To some extent, their literary construction is inseparable from external forces. Rome has a glorious history, and it is also a holy land of Christianity and a city of pilgrimage. Therefore, a large number of writers such as Dante, have come here to leave their literary footprints here. For Byron, Shelley, Henry James, Fitzgerald, Rome provide these writers with romantic love stories, as well as the creative inspiration of detective and spy novels. New York is a city of immigrants. It accepts all cultures with an inclusive attitude. Different literary elements collide and blend here to form a new literary style, which also makes New York a literary pioneer. Literature in New York is always associated with two themes: adventure and wealth. Dreiser's financial trilogy, Edith Wharton's novels and Fitzgerald's The Great Gatsby all describe the life tragedy in New York; The minority writers representing by "the Harlem Renaissance" writers, and Saul Bellow use their personal experience as a template to tell the struggle and suffering of ethnic minorities.

Looking back on the development of the world literature, the image of city in literature seems to exist forever. Bloom's literary Places breaks the linear structure in the original literary works, taking the urban literary relics as the narrative clue to demonstrate writers' life anecdotes and creative experience. This book connects the urban space one by one, so that readers can appreciate literature in history and feel classics in cities. The author skillfully outlines the colorful urban literature, describing the long literary tradition and outlining the literary development track of the six literary capitals. From Hemingway's point of view, "you are mine, the whole city is mine, but I belong to the notebook and pencil in front of me" (Gerrard, 2005, p. 1).

\section{Conclusion}

In Literary Places, Harold Bloom points out that city is the source of all literary genres. City is closely bonded with literature, which offers writers with inspiration and imagination. Writers always choose to live in tranquility to avoid the earthly noise. Meanwhile, city has provided space for writers to socialize. Even today, city can make writers have a sense of place. Given changes in the image of city, city is still regarded as a necessity for literary creation. Through the interpretation of the relationship between city and literature, it can be better to reflect on the history of city and world literature. The future tendency of city literature can also be illustrated clearly.

\section{References}

Dailey, D., \& Tomedi, J. (Harold, B. Ed.). (2005). Literary Places (London). Philadelphia: Chelsea House Publishers.

Foster, B., \& Markowitz, H. (Harold Bloom Ed.). (2005). Literary Places (Rome). Philadelphia: Chelsea House Publishers.

Fu, X. H. (2017). The Literary Code in the Russian Urban Literature. Chinese Russian Teaching, 4, 52-60.

Gerrard, M. (Harold Bloom Ed.). (2005). Literary Places (Paris). Philadelphia: Chelsea House Publishers.

Tomedi, J. (Harold Bloom Ed.). (2005). Literary Places (Dublin). Philadelphia: Chelsea House Publishers.

Wang, C.-H. (1993). City, Literature and History. Taiwan's Sociology Research, 14, 165-180.

Wang, X. Y. (2016). Divine Absence in London Writing: The City Experience in Conrad's the Secret Agent. Hunan University Journal, 6, 113-117.

Woodworth, B., \& Richards, C. (Harold Bloom Ed.). (2005). Literary Places (Saint Petersburg). Philadelphia: Chelsea House Publishers.

Yun, T. (2021). City and Literature. The World Literature Criticism, 3, 245-249.

Zuba, J. (Harold Bloom Ed.). (2005). Literary Places (New York). Philadelphia: Chelsea House Publishers.

\section{Copyrights}

Copyright for this article is retained by the author, with first publication rights granted to the journal.

This is an open-access article distributed under the terms and conditions of the Creative Commons Attribution license (http://creativecommons.org/licenses/by/4.0/). 